\section{International Scientific Journal Theoretical \& Applied Science}

p-ISSN: 2308-4944 (print) e-ISSN: 2409-0085 (online)

Year: $2015 \quad$ Issue: 12 Volume: 32

Published: $30.12 .2015 \quad$ http://T-Science.org
Meyrbek Inkarbekuly Azbergen Candidate of technical Sciences, Professor Taraz state University M.X.Dulati, Kazakhstan azmeirbek@mail.ru

Alexandr Nikolayevich Shevtsov candidate of technical sciences, member of PILA (USA),

Taraz state University named after M.Kh. Dulati, Kazakhstan

Nuradil Meyrbekuly Inkarbek Engineer, LLP "Taraz stroydizayn", Kazakhstan

\title{
THE INFLUENCE OF FREQUENCY OF CYCLIC LOADING ON DEFORMATION OF SOILS
}

Abstract: The article discusses the results of studies of deformation of sandy soils at different frequen-cies of application of repeated cyclic loads, the analysis revealed patterns of deformation, equations to predict the volumetric and shear strains from the action of repeated cyclic effects in the studied range of loading frequencies.

Key words: cyclic load, number of cycles, frequency of loading, volumetric and shear deformation shows the deformation.

Language: English

Citation: Azbergen MI, Shevtsov AN, Inkarbek NM (2015) THE INFLUENCE OF FREQUENCY OF CYCLIC LOADING ON DEFORMATION OF SOILS. ISJ Theoretical \& Applied Science 12 (32): 126-130.

Soi: http://s-o-i.org/1.1/TAS-12-32-25 Doi: crossef http://dx.doi.org/10.15863/TAS.2015.12.32.25

Most of the buildings and structures have not only static (once applied) load and repeated exposure. In these circumstances, the nature of soil bases and structures significantly different from that of their permanent load. The deformation of soil in the process of repeated exposure is accompanied by the development of more plastic strain.

In the General case of full deformation (volumetric and shear) from multiple cyclic effects can be determined by summing the deformations from single load and additional deformation from repeated load application:

$$
\begin{aligned}
& \varepsilon_{v(N)}=\varepsilon_{v}+\Delta \varepsilon_{v(N)}^{p} \\
& \varepsilon_{i(N)}=\varepsilon_{i}+\Delta \varepsilon_{i(N)}^{p},
\end{aligned}
$$

where $\varepsilon_{v}$ and $\varepsilon_{i}$ are the volumetric and shear deformations with a single (static) loading; $\Delta \varepsilon_{v(N)}^{p}$ and $\Delta \varepsilon_{i(N)^{-}}^{p}$ additional volumetric and shear deformations, accumulated during $\mathrm{N}$ cycles of repeated exposure.

In the works [1-7] the results of experimental studies of the deformability of soils under static and quasi-static cyclic influences, the analytical description of the patterns of their volumetric and shear deformation.
To predict additional plastic (volumetric and shear) deformations of $\mathrm{N}$ cycles of quasi-static loading, using the research results, we can write:

$$
\begin{gathered}
\Delta \varepsilon_{v(N)}^{p}=\Delta \varepsilon_{v(1)}^{p}\left(1+B_{v} \cdot \ln N\right) \\
\Delta \varepsilon_{i(N)}^{p}=\Delta \varepsilon_{i(1)}^{p}\left(1+B_{i} \cdot \ln N\right)
\end{gathered}
$$

where $B_{v}$ and $B_{i}$ are the experimental parameters.

The magnitude of the additional plastic volumetric strain and shear strain from the first loading cycle $\left(\Delta \varepsilon_{v(1)}^{p}\right.$ and $\left.\Delta \varepsilon_{i(N)}^{p}\right)$ is well approximated by the expressions

$$
\begin{aligned}
& \Delta \varepsilon_{v(1)}^{p}=\alpha_{v}\left(\sigma_{i} / \sigma_{i}^{*}\right)^{\beta_{v}} \cdot \ln \left(n / n_{o}\right) ; \\
& \Delta \varepsilon_{i(1)}^{p}=\alpha_{i}\left(\sigma_{i} / \sigma_{i}^{*}\right)^{\beta_{i}} \cdot \ln \left(n / n_{o}\right),
\end{aligned}
$$

where $\alpha_{v}, \beta_{v}, n_{o}, \alpha_{i}$ and $\beta_{i}$ are the experimental parameters.

The following research results are an extension of these works to assess the impact of the length of the cycle of repeated triaxial loading on the deformability of the soil.

To study the influence of frequency of cyclic loading on the patterns of development of deformations in soils conducted experiments on sandy soils the average density of the addition. The experiments were performed in triaxial compression devices C-62 design Anbergen M.I. [2,5,6,8]. In these devices for the first time in practice, 


\begin{tabular}{|c|c|c|c|c|c|c|}
\hline Impact Factor: & $\begin{array}{l}\text { ISRA (India) } \\
\text { ISI (Dubai, UAE } \\
\text { GIF (Australia) } \\
\text { JIF }\end{array}$ & $\begin{array}{l}=1.344 \\
=0.829 \\
=0.564 \\
=1.500\end{array}$ & $\begin{array}{l}\text { SIS (USA) } \\
\text { PИНЦ (Russia } \\
\text { ESJI (KZ) } \\
\text { SJIF (Morocco }\end{array}$ & $\begin{array}{l}=0.912 \\
=0.179 \\
=1.042 \\
=2.031\end{array}$ & $\begin{array}{l}\text { ICV (Poland) } \\
\text { PIF (India) }\end{array}$ & $\begin{array}{l}=6.630 \\
=1.940\end{array}$ \\
\hline
\end{tabular}

experimental studies of soil applied widely used in engineering a system "back pressure" [9], which allowed to eliminate the drawbacks of existing devices: leakage of working fluid and friction at the contact "stem-Bush". The use of this system led to a significant increase in the reliability of the obtained results. General view of the experimental setup is presented in figure 1 and the scheme is shown in figure 2 .

The test was subjected to a uniform sandy soils are of two types: the sand is fine and medium size.
The values of the duration of the loading cycle $\left(t_{\Perp}\right)$ was taken equal to $60 \mathrm{~min}$., $60 \mathrm{sec}$. and $10 \mathrm{sec}$.

The results show that the values of the additional plastic strain $\Delta \varepsilon_{v(N)}^{p}$ and $\Delta \varepsilon_{i(N)}^{p}$ the number $N$ at different degrees of approximation of the stress state $\sigma_{i} / \sigma_{i}^{*}$ and to limit the degree of discharge $n$ (the ratio of quantities of cyclic and static stresses) shows that the values of these strains increase with increasing number of loading cycles, and increment their decrease from cycle to cycle.

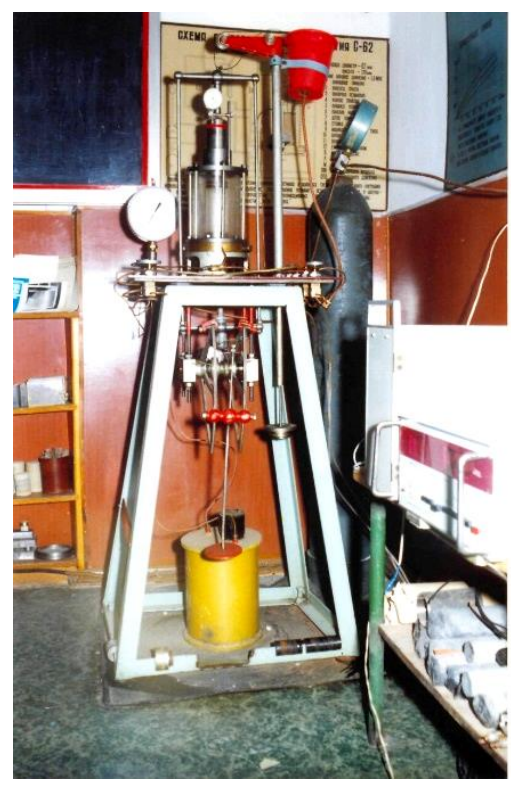

Figure 1 - Device for testing of soils under conditions of triaxial compression design Anbergen M. I.

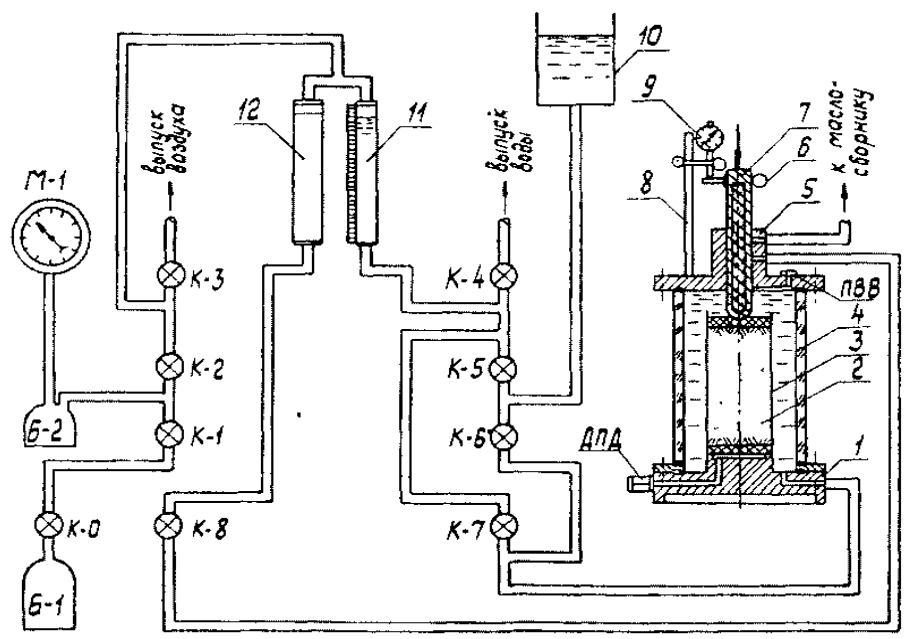

1 - base unit; 2 - soil sample; 3 - rubber; 4 - case; 5 - cover; 6 - console indicator; 7 - rod; 8 - displacement indicator; 9 - the indicator; 10 - tank pressure; 11 - volumemeter; 12 - oil containers; - the container for air; $\mathrm{K}$ valve; $\mathrm{M}$ - manometer; APO - tube venting; DPD - sensor steam pressure.

Figure 2 - Diagram of the device triaxial compression With-62 design Anbergen M. I.

Although General in nature the development of plastic deformation, equal, reducing cycle time has a significant impact on the value accumulated over $N$ cycles of deformation. However, the influence of cycle time on developing additional plastic strain increases significantly with increasing discharge and 


\begin{tabular}{|c|c|c|c|c|c|c|}
\hline Impact Factor: & $\begin{array}{l}\text { ISRA (India) } \\
\text { ISI (Dubai, UAF } \\
\text { GIF (Australia) } \\
\text { JIF }\end{array}$ & $\begin{array}{l}=1.344 \\
=0.829 \\
=0.564 \\
=1.500\end{array}$ & $\begin{array}{l}\text { SIS (USA) } \\
\text { PИНЦ (Russia } \\
\text { ESJI (KZ) } \\
\text { SJIF (Moroccc }\end{array}$ & $\begin{array}{l}=0.912 \\
=0.179 \\
=1.042 \\
=2.031\end{array}$ & $\begin{array}{l}\text { ICV (Poland) } \\
\text { PIF (India) }\end{array}$ & $\begin{array}{l}=6.630 \\
=1.940\end{array}$ \\
\hline
\end{tabular}

the degree of approximation of the stress state to the ultimate. The latter increase largely manifested in terms of shear deformation. Found that when the degree of discharge $n^{(\partial)} \leq 0,2$ (for loading only within the deviatoric part of the trajectory) does not occur in the development of plastic deformation (volumetric and shear). The cycle affects not only the values of accumulated strain, but also determines the number of cycles in which there is a stabilization deformation.

Reducing the duration of the loading cycle for investigated soils in all cases leads to an increase in the stable values of additional plastic deformation (volumetric and shear). The decrease $t_{u}$ from 60 minutes to 60 seconds slightly affect the values of the additional plastic deformation of the sand is mediumlarge and this effect is almost independent of the soil moisture. Sand is fine to change the length of the cycle in a specified range leads to a significant increase in values of additional plastic strain, maximum value of which corresponds to $t_{u}=10 \mathrm{sec}$. Given the recent, study of the influence of cycle time on the development of additional plastic deformation of the soil is made more for the sand is fine.

Data processing the results of experiments conducted with the fine sand show that the additional dependence of plastic deformation from the logarithm of the number of cycles in the General case of nonlinear (Fig.3) and the dependence of the reduced deformation of $K_{(N)}$ (the ratio of additional deformation accumulated during $N$ cycles and the first cycle of loading) from the logarithm of the number of cycles $\mathrm{N}$ is the same for all values of stress in hydrostatic compression, the degree of approximation of the stress state and to limit the degree of unloading (Fig.4). This suggests that decreasing the duration of the loading cycle $t_{u}$ in the investigated range, as well as under quasi-static cyclic loading (when $t_{u}=60 \mathrm{~min}$ ), there is a similarity of the process of developing additional plastic strain with increasing number of cycles, characterized by the deformation is given $K_{(N)}$. This allows us to state that the deformation is a function only of the number of loading cycles.

The nonlinearity according $K_{(N)}(\ln N)$ declared that when the duration of the loading cycle $t_{u}=10 \mathrm{sec}$ the accumulation of additional plastic strain in the first cycles occurs with much less intensity than under quasi-static cyclic loading. This is due to dynamic loading conditions in which inertial forces do not have time to yield a substantially dense packing of soil particles on the first 10-12 cycles, which is consistent with the results of [10]. Upon further loading, the intensity of the accumulation of additional plastic strain, characterized by a given deformation is linearly dependent on the number of cycles. It follows that for soils experiencing a large number of cycles of dynamic effects, the dependence $K_{(N)}(\ln N)$ in a certain range (from $N^{\prime}$ to $N$ ) can be taken linear.
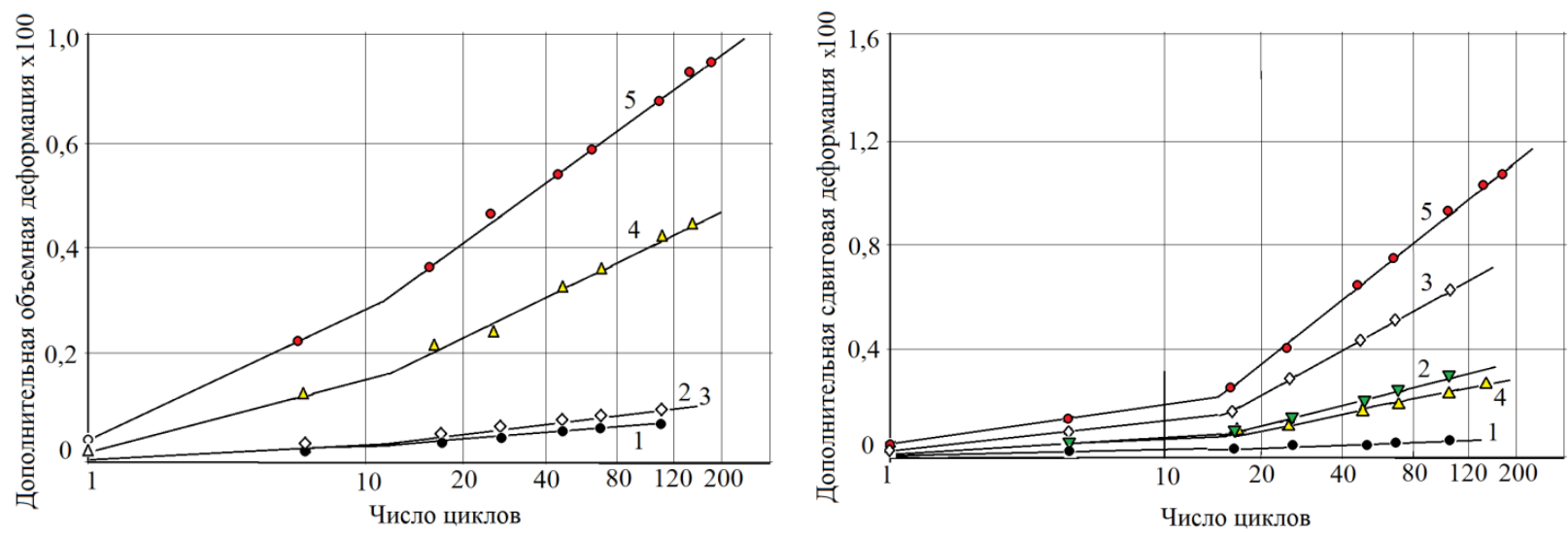

Figure 3 - The dependence of strain $\Delta \varepsilon_{v(N)}^{p}$ and $\Delta \varepsilon_{i(N)}^{p}$ number of cycles: 1, 4, and 2, 5, and 3 for different values of the degree of approximation of the stress state and to limit the degree of unloading. 


\begin{tabular}{l|lrl|l|ll} 
& ISRA (India) & $=\mathbf{1 . 3 4 4}$ & SIS (USA) & $=\mathbf{0 . 9 1 2}$ & ICV (Poland) & $=\mathbf{6 . 6 3 0}$ \\
Impact Factor: & ISI (Dubai, UAE) $=\mathbf{0 . 8 2 9}$ & PUHU (Russia) $=\mathbf{0 . 1 7 9}$ & PIF (India) & $=\mathbf{1 . 9 4 0}$ \\
& GIF (Australia) & $\mathbf{0 . 5 6 4}$ & ESJI (KZ) & $=\mathbf{1 . 0 4 2}$ & & \\
& JIF & $=\mathbf{1 . 5 0 0}$ & SJIF (Morocco) $=\mathbf{2 . 0 3 1}$ & &
\end{tabular}
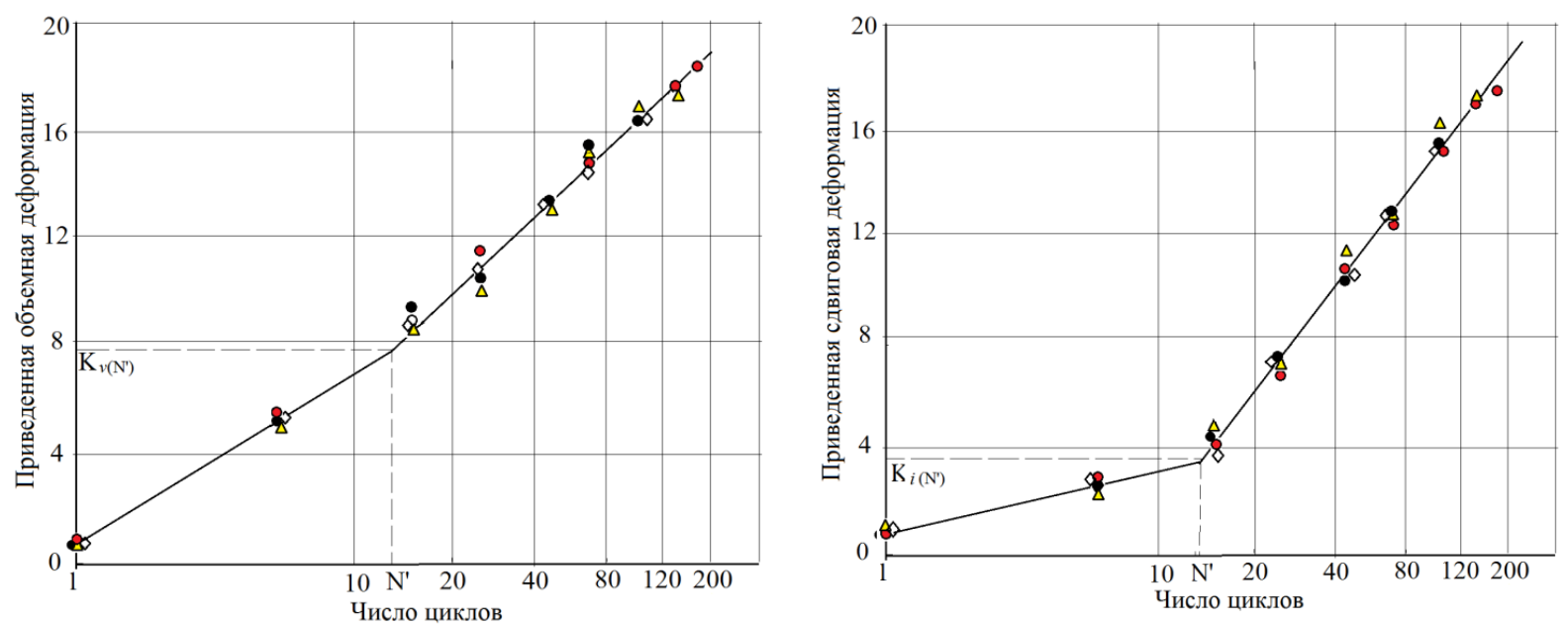

Figure 4 - Dependence of the reduced deformation $K_{v(N)}$ and $K_{i(N)}$ number of cycles under different values of stress in hydrostatic compression, the degree of approximation of the stress state and to limit the degree of unloading.

Then the dependence of the reduced volumetric and shear strain number of cycles at different frequencies of application of repeated load can be described by functions

$$
\begin{aligned}
\Delta \varepsilon_{v(N)}^{p} & =\Delta \varepsilon_{v\left(N^{\prime}\right)}^{p}\left[K_{v\left(N^{\prime}\right)}+B_{v} \cdot \ln \left(N / N^{\prime}\right)\right] \\
\Delta \varepsilon_{i(N)}^{p} & =\Delta \varepsilon_{i\left(N^{\prime}\right)}^{p}\left[K_{i\left(N^{\prime}\right)}+B_{i} \cdot \ln \left(N / N^{\prime}\right)\right]
\end{aligned}
$$

where $\Delta \varepsilon_{v\left(N^{\prime}\right)}^{p}, \Delta \varepsilon_{v\left(N^{\prime}\right)}^{p}, K_{v\left(N^{\prime}\right)}, K_{i\left(N^{\prime}\right)}, B_{v}, B_{i}$ and $N^{\prime}$ experimental parameters determined from experiments under triaxial compression.

A comparison of the calculated and experimental prediction of deformation values shows the correctness of the chosen approximations and the use of equations (1), (2) and (9), (10) to predict the volumetric and shear deformations with repeated cyclic effects in the studied range of loading frequencies.

\section{References:}

1. Vorontsov EI, Azbergen MI (1987) Otsenka vliyaniya tsiklicheskogo nagruzheniya peschanykh gruntov na ikh deformatsiyu / Sb. nauchnykh trudov Gidroproekta, vyp. 124. Moscow: 1987. - pp.141-147.

2. Azbergen MI (1997) Nelineynaya deformiruemost' grunta i uchet povtornosti nagruzheniya - Almaty: Gylym, 1997. -92p.

3. Azbergen MI (2000) Opisanie nelineynogo deformirovaniya gruntov pri razlichnykh usloviyakh ikh raboty i vozdeystviyakh / Trudy 1-go Tsentral'no-aziatskogo geotekhnicheskogo simpoziuma. - Astana: 2000.

4. Azbergen MI (2001) Deformatsii gruntov pri trekhosnom szhatii (na kazakhskom yazyke).Karatau: RITs AGTU, 2001. -94p.
5. Azbergen MI Nekotorye voprosy geotekhniki. - Almaty: Evero, 2012. -116 p.

6. Azbergen MI (2005) Deformatsii gruntov pri trekhosnom szhatii (na kazakhskom yazyke).Taraz: Format-print, 2015. -115 p.

7. Azbergen MI, Shevtsov AN (2014) Dispersedphasic soil model and given the frequency of loading. - International scientific jornal “Theoretical \& Applied Science", 12(20), 2014. - pp.94-96. doi: http://dx.doi.org/10.15863/TAS.2014.12.20.20

8. Zaretskiy YK (1988) Vyazkoplastichnost' gruntov i raschety sooruzheniy. - Moscow: Stroyizdat, 1988. -352 p.

9. Vorontsov EI, Chernilov AG (1981) Ustroystvo dlya opredeleniya prochnostnykh i deformativnykh kharakteristik obraztsa grunta. 


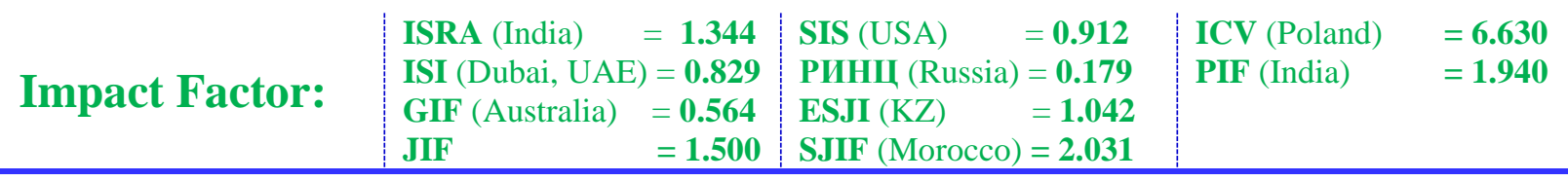

Avtorskoe svidetel'stvo №1040037 ot 13 oktyabrya $1981 \mathrm{~g}$.

10. Shumovskiy VP (1967) Deformativnost' osnovaniy iz nesvyazannykh gruntov pri povtornykh nagruzkakh./ V sb. "Raschet i issledovanie zakrytykh kranovykh estakad". Kiev: Budivel'nik, 1967. - pp.129-146. 